\title{
eudaimonia
}

Journal for Legal, Political and

Social Theory and Philosophy

No. 5 - 2021.

Published by

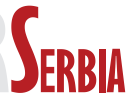

Journal for Legal, Political and

Social Theory and Philosophy

VALIDITY OF THE 1918 UNIFICATION OF MONTENEGRO AND SERBIA AN INTERNATIONAL LEGAL THEORY APPROACH

Matija Stojanović

Pages: 143-164 

Matija Stojanović ${ }^{*}$

\section{VALIDITY OF THE 1918 UNIFICATION OF MONTENEGRO AND SERBIA - AN INTERNATIONAL LEGAL THEORY APPROACH}

In this paper, the author will critically reexamine the 1918 unification of Montenegro and Serbia, challenging the views which claim that it had no legal basis in the then-valid (international) legal order. The author disregards these claims made by the critics of the unification by exposing their methodological and logical inconsistency. In doing so, by citing original documents the author attempts to actually recreate the adjudicating process by which this question had been solved within the realm of the international law and, in doing so, he brings the reader's attention to certain theoretically interesting aspects of the international law, such as its overall nature, its adjudicating process and its adjudicating bodies (institutions), which are of utmost theoretical importance.

Key words: Kingdom of Montenegro, 1918, Assembly of Podgorica, Legal Recognition, Kingdom of Serbs, Croats and Slovenes.

\section{INTRODUCTION}

In November of 1918, a group of people from Montenegro, with the support of the Allied and especially Serbian powers, constituted an Assembly whose task was to express the will of Montenegrin people as in regards of their eventual unification with the Kingdom of Serbia. Each Montenegrin county was to choose representatives who would eventually constitute an Assembly in the city of Podgorica. On $28^{\text {th }}$ of November, after having chosen the local representatives, the Assembly was constituted and it reached the decision to overthrow the then-reigning King Nicholas of Montenegro and to have Montenegro join the Kingdom of Serbia (which would later form the Kingdom of Serbs, Croats and Slovenes (SCS), which was renamed "Kingdom of Yugoslavia" in 1929).

The author is an independent researcher and a master of laws, mato.sto1@ 
The unification of Montenegro and Serbia has been a subject of hot political and legal debates ever since it occurred. A lot of what was written, both in attempt to justify and dispute this event, could not break free of service to specific political agenda it was trying to promote. This produced a lot of works which analyzed this event, not strictly from a legalistic point of view, but rather a political or emotional one. Because of this, many questions which are of greatest theoretical interest have been overlooked and denied the attention they truly deserve.

One of such questions concerns the legal basis of this unification, as well as the procedure of its validation. Considering the fact that the subject matter is concerned with the faith of a specific state (Montenegro), i.e. of a national legal order, its validity can be judged either according to the terms of the specific national legal order or according to the terms of the international legal order. If we choose to judge the unification from the standpoint of the national legal order of Montenegro, that method would normally come down to the question as to whether this unification had any ground in the positive legal order of that country, foremost its constitution; whereas the international point of view would be concerned with whether the unification had any grounds in the then-existing international legal order. Therefore, in order for this unification to be deemed valid, it must base its validity on either of these two grounds. Of course, as one does not automatically presume the other, it is possible for the unification to be valid from the point of international law and not be valid from the point of national law and vice-versa.

Many of the writers who challenged the validity of the unification, did it by indicating that it had no legal basis in the then-existing national legal order of Montenegro, specifically in the Constitution of 1905 which was, as they claim, still in power in Montenegro in 1918. They claim that the Assembly of Podgorica had been constituted contrary to this Constitution, and that it was, therefore, an alien and revolutionary body which hijacked Montenegro and, contrary to all law and honesty, had it merged with Serbia. They go on to prove how the procedure according to which the representatives been elected in this Assembly, as well as the Assembly in general, had no grounds in the Montenegrin legal order, therefore rendering its decisions, from the standpoint of the national law, invalid (Šuković 2003).

However, these authors easily disregard the fact that the legal order of Montenegrin Kingdom, at the time of unification, was not effec- 
tively (de facto) in power for almost three years prior to the constitution of the Assembly and the unification of Montenegro with Serbia. Namely, the national legal order of the Kingdom of Montenegro had been effectively suspended in favor of the Austrian occupational regime by the end of February 1916, and this state remained in power merely months before the actual unification had been declared. With the arrival of the Allied troops, the Austrian regime withered away, but the old Montenegrin legal order was not re-established. This means that the Montenegrin legal order had no de facto existence/presence on the territory of Montenegro at the time unification had been declared. The King and the Government of Montenegro were in exile, their army, as well as their Assembly, were disbanded. This means that from the national point of view, which regards the validity of unification from the standpoint of the Montenegrin constitutions, runs into a huge problem - the fact that it is unable to prove that the Montenegrin legal order existed/was valid at the time the unification had been declared and it is only natural that any statement concerning the validity of a certain act in the light of the specific legal order must presume the existence of such an order.

This is exactly where the critics of the unification fall short. For they, in order to overcome the fact that the Montenegrin legal order hadn't actually have been existent/valid at the time of the unification, point out that it had existed according to the terms of the international law throughout the occupation and afterwards. This, they claim, is easily provable through the fact that King Nicholas of Montenegro and his government had been officially recognized as the representatives of the Kingdom of Montenegro, which is to say an existent country, by the Allied powers and other countries for the whole duration of the war. Thanks to the fact that they enjoyed this sort of recognition, the critics claim that the Montenegrin country and legal order continued to exist (Šuković 2003, 243-246).

However, the fact that King Nicholas continued to be recognized as the de jure sovereign of Montenegro during his time in exile is a legal reality only within the realm of international law, in other words - this statement is only true if we recognize the Second and Fourth Hague Treaty on Belligerent Occupation from 1899 and 1907 which treat occupations as a temporary states which does not strip the rightful sovereign of his title as a valid source of law:

"The main pillar of the law of belligerent occupation is embedded in the maxim that the occupation does not affect sover- 
eignty. The displaced sovereign loses possession of the occupied territory de facto but it retains title de jure. For its part, the Occupying Power acquires possession - with jurisdictional rights (see supra 104) - but not title. Undeniably, divested of possession, at least temporarily, the title of the territorial sovereign is considerably weakened and reduced to a naked title'. Nevertheless, the sovereignty of the displaced sovereign over the occupied territory is not terminated. Indeed, it is not even suspended (as inaccurately asserted by some commentators). In the words of L. Oppenheim,' $[t]$ here is not an atom of sovereignty in the authority of the Occupying Power". (Dinstein 2009, 49).

Namely, if we operate within these terms, the statement that occupying powers gained no sovereignty over Montenegro (nor have they suspended the Montenegrin legal order) is true. And hence, this country, alongside its sovereign, continued to legally exist within the international legal order, having its national legal order tainted only temporarily, remaining otherwise nominally valid. Therefore, King Nicholas had every legal right to reinstate his de facto rule over Montenegro once the occupation was over.

The fact that the occupying Austrian forces did indeed keep their rule over Montenegro under the framework of the Fourth Hague Convention cannot be disputed (Rakočević 2018, 362-380). However, by deciding to base the validity and existence of the Montenegrin legal order on these grounds, that is, the grounds of international law - we necessarily came to accept a monist theory of law with the supremacy of international law within it. This means that the only way for the Montenegrin legal order to exist is within the context of validity and superiority of the international legal order. However, consequently holding onto such logic carries with it a whole set of unwarranted consequences which do not benefit the cause of those who wish to dispute the legality of the 1918 unification, for this unification too based its validity on the premises of international law. Therefore, to challenge the validity of the unification by challenging the international law upon which the unification had been eventually based, is to deny the very source of validity and existence of the very Montenegrin legal order (based on which we base our claim that the unification hadn't been legal) - destroying therefore the context within which the national Montenegrin legal order is existent and depriving yourselves of the basis to challenge the unification within the terms of national legal order of Montenegro. 
Therefore, by basing the ultimate validity and existence of the Montenegrin legal order on the grounds of international law, we must stay consistent and recognize it as to the ultimate measure of all validities, both the ones which are and the ones which are yet to come. Therefore, we cannot soundly object to something which would eventually be rendered valid within the international legal order with the claim that it is invalid in the light of the national order, for it means forgetting the fact that the ultimate source of the validity of that particular national order is too within the international legal order which we now challenge - it means forgetting the fact that the national legal order drinks from exactly the same "well of validity" as the legal reality we try to challenge.

The objective of this article is to prove that the international legal order, based on the validity of whose specific norm the overall validity of Montenegrin legal order had derived, had eventually deprived the Montenegrin order of it validity recognizing it's unification with Serbia, on the basis of another norm of its own. In doing so, we will open a broader question of the overall nature of the international law and it's adjudicating processes. For example, in a conventional legal order - we could imagine a situation in which a certain person is deprived of the possession of a certain item by another person. The person deprived of the item will be able to eventually sue the current holder of the item on the basis that he is holding it without a proper legal basis. This person would, in his lawsuit, claim and try to prove his right of possession and demand restitution on the basis of a specific norm of that particular legal order. On the other hand, the other side could object that he too is holding this item in accordance with another norm of that same order. The court would then adjudicate as to whose claims holds stronger ground within that legal order. It might be that both of the norms which the two sides refer to exist within the order, it might also be that they are mutually exclusive - but the most probable case is that one of these two norms is deemed to be in a certain way superior to the other one (according to the specific derogative principle) and thus, according to the law - as capable to derogate the validity of the previous one.

What happened with Montenegro comes down to such legal dynamics. However, international legal order is an unconventional legal order, and it especially was at the time immediately after the First World War, when this unification took place. Back then, the international legal order was lacking most of the institutions we take for 
granted in a national legal order. It had no conventional courts, nor did it have a specific legislating body. But this still does not mean that it was deprived of an adjudicating and legislative function overall. As M. Jovanović points out, whether the validity of a certain norm is satisfied is "normally ascertained by law-applying institutions, most prominently courts." (2019, 81), however as no such institution was to be found at the time:

"In pre-World War I Europe, whenever a problem arose in relations between the states, international congresses and conferences were summoned." (Jovanović 2019, 160), "In general, peace treaties, following some major international conflicts, were for a long time the main "institution" of international law-making that served to extend membership to newly admitted sovereign states" (Jovanović 2019, 196).

We see that within the realm of international law, at this point of history, we can regard the Peace Conferences as the relevant adjudicating body which was called upon to judge as to what can be regarded as lawful and what not. Additionally, we see that for most of history, unlike the national legislative bodies, these conferences did not draw any general principles upon which they would base their decisions. It is specifically important that these conferences "did not install any forward-looking allocative principle that could subsequently have been invoked for the distribution of sovereign statehood. Toward the end of World War I, President Wilson famously proposed national self-determination as a new allocative principle that was supposed to replace the practice of arbitrary creation and dismemberment of states through the process of balancing power relations between major European states" (Jovanović 2019, 197).

Despite the fact that the question as to whether the principle of self-determination was accepted as a positive norm of the international law in post-WW1 world, and if yes, to what degree, is open, ${ }^{1}$ what we see here is the fact that the law-making and the adjudicating bodies

1 Shaw writes: "This principle, which traces its origin to the concepts of nationality and democracy as evolved primarily in Europe, first appeared in major form after the First World War. Despite President Wilson's efforts, it was not included in the League of Nations Covenant and it was clearly not regarded as a legal principle" (2003, 225), Fisch writes: "From a legal point of view, the situation was, however, still clear at the end of the war. The right of conquest still applied, and the right of selfdetermination was merely a watchword and postulate and not by any means positive international law" $(2015,138)$. 
were, at the time, merged within a single body - which carried both the legislative and adjudicative functions. The international conferences were at the same time called upon to legislate what is law and to adjudicate as to whether a certain action is in accordance with such law. They were, therefore, virtually unbound by higher principles in legislating and adjudicating.

Structurally speaking, the main difference between such a body and a conventional court is the fact that the institution of conference is down to its very core contractual in its nature. While adjudicating, instead of following a simple syllogism and deducing the legality of the particular on the basis of its accordance with the general rule, it is actually constrained in deciding the legality of a certain act by nothing other than the will of its members. This unrestrainedness is a natural consequence of merging the legislative and adjudicating functions within a single body. If we further deconstruct these Peace Conferences we will see that they are nothing other than forums where the subjects of the international order, that is respective states, come together in order to reach agreements as to what will in future be regarded as legally valid and sanctioned by these respective powers. We thereby uncover the true nature of international law, which is to its core a contractual normative order - it is, as Shaw points out, a "network of relationships existing primarily, if not exclusively, between states recognizing certain common principles and ways of doing things" (Shaw 2003, 5-6).

\section{THE ADJUDICATING PROCESS}

During the war, Montenegro had been put under an occupational regime. The courts continued to implement the Montenegrin civil law, but not the constitutional and criminal norms. However, by the second half of 1918, the Allied forces, with the significant participation of the Serbian army, managed to break the Salonika front and open the doors for the quick liberation of the Balkan Peninsula from the Austrian rule. This encouraged a part of Montenegrin population to organize an uprising and liberate the country from the Austrian occupation. First to be liberated were the northern parts of the country, while the rest of Montenegro was soon to follow. On the liberated territories, the armed forces of the Montenegrin people set up their own temporary institutions and rules. These institutions were fragmented 
- each city had its own organization, some areas enjoyed virtually no order, while the others rushed to proclaim their unilateral unification with the Kingdom of Serbia. Soon enough, the Allied forces entered Montenegro and the "normative mosaic" had been eliminated thanks to the order set up by the Allied troops (Вујовић 1962, 310, 697).

Having his country liberated from the Austrian occupation, King Nicholas deemed that it would be rightful that he, in accordance with the Hague treaties, returns to his country and re-establishes his rule. The Allied forces which entered Montenegro were under the supreme command of the French general Louis Franchet d'Espèrey, and on $22^{\text {nd }}$ of October, the French officials sent a letter to the King Nicholas assuring him that the "The French Government has absolutely no ambitions to interfere in inner issues of one allied country. It is clear, therefore, that when the French army enter Montenegro, they will not be taking any stance other than that of recognition of the lawful power of King Nicholas. Therefore, in the name of that sovereign shall the administration by the respective allied institutions take place" (Vukčević 2000, 37). We see that at this point the Allied powers did, in accordance with the Hague treaties, regard King Nicholas the rightful sovereign of Montenegro, also recognizing his right to re-establish his rule.

Shortly after receiving this letter, the King expressed his wish to be allowed to return to his country and reestablish his regime. The French were, however, of another opinion, insisting that it would be better if he remains in France until the dusts settles in the newly liberated Montenegrin territories, ensuring the King that: "the troops under the command of the general Louis Franchet d'Espèrey shall miss no opportunity to ensure that in Your Kingdom every order be protected and the constitutional prerogatives respected, as well as the liberties of the Montenegrin people" (Vukčević 2000, 38).

We can witness that this letter, which was dated on $4^{\text {th }}$ of November 1918, holds a slight, but significant, distinction when compared to the previous one. Despite the fact the recognition of the King's rightful claims to the throne is present in both of them, we see that in the second letter it is joined with the recognition another normative principle based on which the fate of Montenegro can be decided - the liberties of the Montenegrin people. Therefore, we see that within the minds of the Great powers, the adjudicating process as to what holds a stronger claim to represent Montenegro had already started. By insisting that the Allied troops will also respect "the liberties of the Montenegrin people" the ter- 
rain for the expression of the right of self-determination of the Montenegrin people was being set. The future of Montenegro will be, from the standpoint of international law, solved through weighting between these two normative principles - either returning it to its previous sovereign, King Nicholas, or following the expressed will of the Montenegrin people.

Shortly after the previous letter, on $12^{\text {th }}$ of November, following the order of the Allied troops by which the popular irregular forces, as well as their local rule were disbanded, a new letter arrived. The French officials ensured King Nicholas that he has no reason to worry as to the fate of the Montenegrin order, for the "The French Government (...) shall not concede to any attempt aimed towards pressuring the will of the Montenegrin people and sabotaging his lawful yearnings" (Vukčević 2000, 38). We see that at this point, the weight steadily shifted in favor of the democratic yearnings of the people, and that King's rights were no longer mentioned. This change didn't come out of a blue, for on the terrain, with the help of Allied and especially Serbian forces, a "Great National Assembly" in which the unification of Montenegro and Serbia as well as the dethroning of King Nicholas were to be proclaimed, was being organized in a hasty manner.

A month prior, on $24^{\text {th }}$ of October, a group known as the Temporary Executive Committee was formed having declared the "Rules on electing the electors for the Great National Assembly" based on which a nation-wide election of electors had taken place on $6^{\text {th }}$ of November. The elected electors had then gathered on $24^{\text {th }}$ of November in Podgorica in order to cast their votes on the issue of "the future legal and statehood status of Montenegro and the election of the National executive committee which would have the task of administrating the Assembly and bringing its decision to life" (Bojović 1989, 7).

On its final session, on $26^{\text {th }}$ of November, the Assembly in Podgorica decided that:

"On the basis of the proclaimed principle - self-determination of the people, which was accepted and proclaimed as the condition of the future world peace by (...) the president of the United States, Mr. Wilson, and accepted by all our great allies and friends, England France and Italy - the Great National Assembly of the Serbian people in Montenegro, (...) declares:

1.) That the King Nicholas I of Petrović-Njegoš, along with his $d y$ nasty, be dethroned of the Montenegrin throne. 
2.) That Montenegro shall, along with brotherly Serbia, be united in one country under the dynasty of Karadjordjevic, so it would, united in such manner, enter into the common Homeland of our three-named nation of Serbs, Croats and Slovenes (...)" (Bojović 1989, 184-189).

The leaders of the unionist parties soon finalized their plans and the unification was de facto completed. However, the fact that a certain body expressed what they deemed to be the will of Montenegrin people as to their self-determination does not by itself warrant the conclusion that, legally speaking, the right to self-determination had truly been invoked. The ones who finally decided upon these question were the adjudicators of the then existing international legal order. A legal scholar cannot place himself, legally speaking, in a position of an adjudicator and a judge. His judgement can hold only doctrinal value and never can it hold legal value per se. Those who were called within the normative framework of the international legal system to place their judgement as to what is to be deemed lawful are the only ones whose judgement matters, for their judgement is the only legal judgement of the specific issue. As Kelsen points out: "If a legal order in an abstract rule attaches certain consequences to a certain fact, it must (...) determine a procedure through which the existence of the fact, in a concrete case, is ascertained by a competent authority. In the realm of law, there is no fact "in itself," no immediately evident fact, there are only facts ascertained by the competent authorities in procedure determined by law" $(2006,221)$.

This means that we must answer which body, and in what procedure, ascertained the following facts as a valid basis upon which a legal judgement which would warrant the disbandment of the Montenegrin state and its unification with Serbia would be reached. This returns us to the previously mentioned problem of adjudication process in the international law.

\section{MONTENEGRIN QUESTION IN FRONT OF THE PARIS PEACE CONFERENCE}

The proclaimed unification of Montenegro and Serbia hadn't been ratified at once neither by the International Community nor by a Conference which was called upon in order to regulate the international affairs following the First World War. The first to accept this unifi- 
cation and cut its ties with Montenegro was, naturally, the Kingdom of Serbia (Vujović 1962, 391). This action was frowned upon by the British government which brought to Serbia's attention that unilateral acceptance of such actions is a dangerous precedent and that territorial changes should only be adjudicated within an International Conference which was to take place (Vujović 1962, 391). The international community was unanimous in accepting that the fate of Montenegro, along with the fate of other states following the First World War, was to be solved within an International Conference.

The conference in question was to be the Paris Peace Conference. During the preparation of this conference, on $13^{\text {th }}$ of January 1918 , the High Council of the Conference decided that: "Montenegro will be represented by one delegate, as to the manner in which this delegate shall be determined, this question shall be solved only after the political situation of this country becomes clear"(Vujović 1962, 408). This norm unveils two very important things. The first is the fact that the Montenegrin state, legally speaking, continued to exist within the realm of international law; and the second being the fact that the question as to who can be regarded as the proper representative of this country was open. The reason for the letter lies in the fact that the solution of the question of representation of Montenegro presupposed the solution of the question of validity of the 1918 unification of Montenegro and Serbia. For, if the unification was legal, the representatives of the unionist policy could've been regarded as the legitimate representatives of the Montenegrin people, therefore, recognizing them as the representatives of Montenegrin people would mean recognizing the unification upon which they gained rule as legal. On the other hand, if the conference had regarded King Nicholas as the valid representative, it means that it would have further legalized his claim on rule, rendering the Assembly of Podgorica, as well as its decisions, legally invalid and void.

However, only five days prior to the official start of the Conference it had been declared that the Montenegrins will receive an opportunity to freely express their stance as to in what country should they live in (Vujović 1962, 408). This means that the Great Powers were still unsure as to whether the Assembly of 1918 had truly represented the will of the Montenegrin people (or whether King Nicholas still can be regarded as a rightful sovereign). Additional inquiries were needed. Procedurally speaking, we could say that the adjudicating process was still ongoing and that additional evidence as to whether the decisions 
of the Assembly truly reflected the will of the Montenegrin people had to be collected.

Various envoys had been sent to Montenegro in order to investigate as to whether the decision of the Great National Assembly truly reflected the will of the people. The reports generated were not unanimous - some reported in favor of the assembly, some against it (Vujović 1962, 394). However, as time passed - it became probable that the Conference implicitly considered Andrija Radović, the leader of the unionist policy from Montenegro as the legitimate representative of Montenegro (Vujović 1962, 409). This was especially concerning considering that he acted within the delegation of Kingdom of Serbs, Croats and Slovenes (Mitrović 2019, 28, 41). Radović always presented and himself as a representative of Montenegrin people and signed himself in such a capacity. The fact that he acted within the Yugoslav delegation served as a further indication towards the confirmation of the unifications validity (Mitrović 2019, 240), for if the unification was legal, the delegate of the Montenegrin people would've been a part of the SCS delegation, the same way Montenegro would be part of the Kingdom of SCS. Although no official verdict supported this claim, it does undoubtedly serve as a proof that the will of the adjudicators was moving in a specific direction.

Various statements expressed by the governments of the Allied countries further supplement this stance. In June of 1919, answering the question of a British parliamentary as to whether the Kingdom of SCS has been recognized by His Majesty's Government and how does this reflect the will Montenegrin people and their right to self-determination - His Majesty's Government responded that the Kingdom of SCS has been recognized by the Allied powers, and that the Montenegrin question falls under the jurisdiction of the Peace Conference. A similar question arose before the French government which was a bit more precise in their answer, specifying that the "Montenegrin question has not yet been directly discussed." (Vujović 1962, 391).

We see that both officials of UK and the French Republic were unanimous in the decision that the faith of Montenegro falls under the jurisdiction of the Paris Peace Conference, and that it still is a res in iudicum. However, the conference in Paris failed to produce a single document which would explicitly state that the unification of Montenegro with Serbia had either been validated or invalidated. It is clear the unification of Montenegro hadn't been, as late as by the end of 
1919, solved (res iudicata). On November $19^{\text {th }}$ of 1919 , almost a year after the unification de facto took place, the French president assured the Montenegrin King Nicholas that:

"Remaining faithful to its principles and the principles which inspire the Peace Conference, France remains strongly committed to respecting the will of Montenegrin people and it's legitimate yearnings - in such spirit shall French Republic, together with other allies - take part in regulating the issues which refer to Montenegro" (Vukčević 2000, 42).

We see that we can once again translate the Montenegrin question as to whether the unification with Serbia truly reflected the will of the Montenegrin people as to their determination. This means that the criteria according to which the Montenegrin question was to be solved was defined and clear, and that the only question still remaining was whether what happened in Montenegro in 1918 would be recognized by the Great Powers as something which is in accordance with the principle of self-determination. This means that, even a year after the unification took place - the adjudicating process was still ongoing.

On December the $9^{\text {th }}$, within a secret memorandum signed by representatives of France, USA and Great Britain concerning the "Adriatic issue" the following statement was to be found: "The right to control the development of Boyana river (a river in Montenegro, M.S.) shall be vested either to Italy, or the Serb-Croat-Slovene state (...) It is assumed for this purpose will form a part of the Serb-Croat-Slovene state" (Vukčević 2000, 70-71). We see that the adjudicating process hadn't been concluded neither a month later. The question as to whether the unification was to be rendered legally sound was still open.

However, by $21^{\text {st }}$ of January of 1920 the working sessions of the Paris Peace Conference came to an end, failing to produce a single explicit document with regards to the Montenegrin issue. However, this does not mean that the adjudicating process had been stopped. A conviction developed within the actors of international law that the elections for the Constituent Assembly of the newly-formed Kingdom of Serbs, Croats and Slovenes, in which the Montenegrin people will participate, would serve as a perfect chance for the international community to witness another manifestation of the will of Montenegrin people. The turnout of Montenegrins on this election was chosen to be the measure of their true self-determination. If the turnout was to be 
high enough, it would be rendered that the Montenegrins had recognized the unification and its results, if it was not - then it would mean that they still recognize the old order as valid. This view was explicitly stated by Lord Carson in his speech in the House of Lords in March the $11^{\text {th }}, 1920$, and was shared by the other powers as well (Vujović 1962, 393).

This turn of events serves as additional evidence in favor of the view that the Peace Conferences are nothing other than a specific forum upon which a consensus on the subjects of international law is reached upon a certain issue. However, it is important to highlight that it is the consensus which creates law, not the location - for the conferences were held in many different locations - but they always shared one common essence - the fact that within them a consensus between certain powers on a specific issue had been reached. This consensus, which in our case serves the purpose of a adjudicating the legality of the Montenegrin unification, could've too been reached outside the working sessions of the conference, it could've been reached in writing or orally, remotely or in proximity, in one or more meetings, but, structurally, it always comes down to the same thing. The manner in which it is reached is not importance, for it does not change its essence, but only its "formal container". In addition to that, "the formal peace process" following the First World War "did not really end until July 1923" (Neiberg 2017, 9), the talks between the warring parties continued to be held and peace-treaties continued to be reached for more than three years after the end of the Peace conference.

In addition, another proof that the Montenegrin question was not res judicata, but rather a res in judicum is clearly expressed in the following event. Namely, on $16^{\text {th }}$ of November 1920 - The King's Government in Exile filed an application for the Kingdom of Montenegro to be accepted into the newly-formed League of Nations. The French delegate, who was the President of the Political Committee of the League - answered the application in the following manner:

"The question of the present existence of an independent Montenegrin country has never been solved. In the Peace Conference of 1919 Montenegro had been enlisted among the countries participating in the negotiations, but no one had been recognized as qualified to represent it" (this is in relation with the significance such a representation would carry with it, which we already discussed) (Vukčević 2000, 192), he then goes on to elaborate how 
the Great Assembly in which the unification had been declared is itself disputed, concluding with the following claim: "in the eyes of the Yugoslavs, Montenegro has become a part of the Kingdom of SCS, without wanting to prejudicate this question - it seems reasonable not to admit Montenegro to the League, on the basis of a plea of a, less to say, disputed Government which is currently in exile" (Vukčević 2000, 192). Therefore we see that this issue was still awaiting a final verdict.

And this verdict finally came. Only three days later - on $28^{\text {th }}$ of November - the Constituent Elections for the Constitutional Assembly of Kingdom of SCS took place. The turnout was deemed high enough as a specific portion of the Montenegrin population chose to participate in these elections and vote. This participation was, as previously defined, interpreted by the Great Powers as additional evidence as to the true willingness of the Montenegrin people concerning their determination to stay within the Kingdom of SCS. The significance of this election, the fact that it provided the final proof according to which the 1918 unification of Montenegro with Serbia had been finally validated, thereby ending the lengthy adjudicating process in favor of the unification; can be recognized from the following acts:

Foremost in the statement made by the French diplomacy, which wrote to King Nicholas in the following manner: "Dear President, following the instructions of the Government of the French Republic, considering the constituent elections which have been held in Yugoslavia, the population of Montenegro expressed itself: there can be no further doubt in his wish to stay united with the rest of Serb population in the Kingdom of Serbs, Croats and Slovenes, whose existence we officially recognized. The Government of the Republic, thereby, considers the unification of Montenegro to the aforementioned Kingdom to be a done thing. Under such conditions, the Government of the Republic sees no reason to continue its diplomatic relations with the King Nicholas, and has, thereby, decided to cut the Embassy of France in Montenegro" (Vukčević 2000, 11-12).

With this letter, sent in 20 December 1920 - the French government became first of the Allied Powers to explicitly express its statement as to the validity of Montenegrin unification with Serbia and consequently cut its ties with the King Nicholas' Government in Exile, which was in turn ruled to no longer be a valid representative of Montenegrin people. Ohers soon followed - the very same day the 
United States expressed their official stance concerning the validity of the unification, recognizing it and thus severing all ties and recognition of the King's regime. The United Kingdom, as well as the United States followed shortly thereafter (Vujović 1962, 393-394). By this, we see that a consent regarding the Montenegrin issue has finally been reached within the Great Powers. We already said that the only normative acts which existed within the realm of international law back at the time was the consensus of the relevant world powers. This consensus, which consisted in the aligned wills of the world powers could have been reached and expressed either within a single document, or through series explicit or implicit ${ }^{2}$ unilateral statements. Although the decision concerning Montenegro hadn't been reached within a single document, it had been reached through a series of mutually aligned explicit statements of particular states. The content of the decision reached could come down to the following: "Based on the will of the Montenegrin people and their right to self-determination, Montenegro joined the Kingdom of Serbs, Croats and Slovenes and thus ceased to exist as an independent state." The formal container of this decision, as we said, was not unique, but rather evident through a series of explicit statements confirming it.

After having his country lost, in the March of the same year, the old King Nicholas of Montenegro died in exile. The last remaining country to actively recognize Montenegro was the Kingdom of Italy, the Queen of which was the daughter of late King Nicholas. However, by the end of 1922 this recognition too ceased and all remaining nominal representatives of Montenegrin statehood soon ceased to exist as well (Vujović 1962, 399).

\section{THE CHALLENGES TO THEORY OF INTERNATIONAL LAW}

The manner in which the Montenegrin question had been solved sheds a lot of light onto the nature of the adjudicating process within International Law, especially in the context in which no central, constant, adjudicating body is to be found, as was the case prior to the appearance of international tribunals. Before such institutions had

2 The case of constituting a norm through a series of aligned unilateral statements of respective states is best visible in the creation of international legal custom. 
been set up, the consensual roots and nature of international law, the fact that it actually is a "network of relationships" between the states within which a certain normative standard is reached between them, comes to full light.

Therefore we see how one norm of the international law upon which King Nicholas had been recognized as the legal sovereign of Montenegro was eventually derogated by another norm of that same legal order; but we do not see it happening within a classic adjudicating or lawmaking body. Rather, we uncover that the decision and its implementation were achieved in an unconventional, uncentralized, manner - not by a single decision of a single actor, but by a series of unilateral acts of different actors - which in the end all formed one legal statement and a signle norm - the one according to which the Montenegrin state ceased to exist on the basis of self-determination of Montenegrin people.

"The government of a State interested in the existence or non-existence of another State is, it is true, not an objective and impartial authority to decide that question. But since general international law does not institute special organs to create and apply the law, there is no other way to ascertain the existence of facts but the ascertainment of these facts, and that means their "recognition," by the interested governments. Recognition of a community as a State in the sense of international law is only a particular case of the general principle of recognition, that is, the principle according to which the existence of facts to which international law attaches legal consequences has to be ascertained by the governments which are interested in these facts in a concrete case. This is a consequence of the far-reaching de-centralization of international law" (Kelsen 2006, 223).

This brings us to another quite important finding. The fact that concrete actions by subjects of international laws, such as de-recognition of a certain state, are not merely implementations of a certain norm - but rather, at the same time - verdicts and acts of legislation in their own light. For, by de-recognizing Montenegro - the states did not simply abide by a certain positive norm or a verdict, but they actually reached and expressed their verdict on a certain issue through these derecognitions, and not only reached, but also validated the norm of selfdetermination as a positive legal norm. This clearly unveils the contractual nature of the international law - which is visible not only in 
its adjudicating mechanism, but also in the fact that the adjudicating, legislating and executive capacities are often expressed within single acts. This further goes to prove the "rawness" of the international law - a legal order which still is, and especially was at this point of time, a "network of consensus" lacking the institutional structures present in national legal order.

We see that a (de)recognition of a state can, in a situation of an ongoing adjudication of a certain question, express an adjudicating stance regarding the validity of the specific action, or rather the validity of a certain norm in the broader international order. For, through the recognition of a certain action as legal - the countries recognize the norm on which this action had been constituted as legally binding. If enough such aligned stances are expressed, we can rule that an unanimous stance as to, in first place, the existence of a certain norm is reached, alongside it, a stance as to the de facto alignment of the specific factuality with that specific norm is too expressed. By recognizing the concrete cases as valid - the adjudicators recognize the norm behind them as a legal norm. We can therefore conclude that by the derecognitions of Montenegrin Kingdom, the concerned states expressed their stance that, the principle of self-determination of nations, which they accepted as the positive law at the time, had derogated the norm according to which Montenegro had been granted statehood and its King representativeness, validating thus the unification of Montenegro with Serbia valid. A new legal reality was thus expressed, constituted and accepted. However, lacking a unified judicial act - objections can naturally arise. Some can say that - while France, the United Kingdom and the United States, which were, without a doubt, the leading powers of the time, did express their stance through a series of de-recognitions, the other states were not explicit in their expressions - meaning that we cannot conclude that an unanimous decision had been reached on such issue.

We therefore see that in such an environment, a certain insight into the internal aspect of the state-actors is necessary in order for us to conclude upon which, if any, legal grounds did these de-recignition ensue. We therefore see how the admittance of a certain norm, or in other words, the adjudicating process, can be, as we already stated - both explicitly and implicitly accepted, as is the case in creating of legal custom. It is known that legal custom in international law gets constituted not by explicit stances of states, but rather through their factual doings, 
through which their implicit, internal stance, in regards of a specific question is revealed. Such is also the case with the de-recognition of a statehood, in that which we can label as adjudicating by custom. Which is in reality not merely adjudicating, but also legislating. If a relatively unified stance upon a certain question can be deduced from the acts of different States - we can conclude that these States reached an agreement upon a certain question, not only as to the norm according to which a certain issue has to be judged, but also as to the fulfillment of this normative criteria.

\section{CONCLUSION}

It is futile to argue whether the 1918 Assembly truly was or wasn't a manifestation of the Montenegrin's people right to self-determination. The fact that it was interpreted as such by the Great Powers, which were legal adjudicators at the time, is the only interpretation which matters when solving its legality, for it is the only legal evaluation of this event. It is impossible for us to say that the French, American and British officials - the molders of the then-existing international legal order were wrong. They might've been unjust, unfair, wicked or sly - but they couldn't have been legally wrong, for they were the ones who decided what is legal. They were the demiurges of the order, the norm-creators, the norm-interpreters and the norm-executioners, and were thus, legally speaking, infallible. There was no legal reality outside of that which they created, no higher instance according to which their decisions could be valued as either legal or illegal.

It is, thus outside of our capability as legal scholars to adjudicate as to whether something which was a legal reality truly was or was not legal, for its legality does not depend upon our judgement. We can only accept the fact that it was legal and try to explain, for the sake of jurisprudence, how exactly was that legality achieved and what did it all imply. Everything else would be engaging in futile judgements and coming short of our vocation as legal scientists. Our job as legal scholars is not to dispute whether something which has been legal was or was not - but to understand how it came to be legal. This is what legal theory must occupy itself with. A failure to reproduce and explain the process through something which came to be regarded as legal does not deprive the observed phenomena of its legality, but rather deprives the legal theory of its usability. 
In case of the Montenegrin question, we uncovered a series of broader issues which are inherent to the international law, especially its adjudicating process. The norm creators, by their very possibility of norm-creating are legally unconstrained. There is and cannot be an a priori determined content of the norms they pass, for there is no body, norm nor act which would mandate a certain necessary content to these norms. What the content and the prescription of these norms will be depends on the norm-creators and their perceptions of what they deem to be their interests. These interests can be articulated along the lines of a certain principles, as was the case after the WW1, when the principle of self-determination first arose, or they can simply remain unconstrained, manifesting themselves through decisions whose only explanation lies in brute force and power-logics. However, it is important to note how in addition to the fact that the norm creators (legislators) are virtually unconstrained, they also played the part of the adjudicators and executors of the international rules. They both set the rules and imposed them.

Therefore, legally speaking, we had a certain legal reality consisting in the existence of the Montenegrin state and its representation by King Nicholas. This legal reality was produced by the international legal order, which provided a ground not only for the constitution of a national legislature, but also for its survival during the Austrian occupation. For, if we claim that the Montenegrin legal order owed its validity and existence not to the recognition the international legal order provided it with, that its measure of existence was not in its international recognition but rather in its brute force, its factual existence and effectivity - we must conclude that such a stance inevitably leads us to the conclusion that once this brute force and effectiveness stopped, the national legal order of Montenegro ceased to exist. However, if we agree that the existence of this order was measured by the recognition the international legal order provided it with, than we can conclude that it continued as long as this recognition continued - that a temporary loss of its force and effectiveness did not necessarily lead to its extinction, but merely to a temporary compression which was lifted once the occupation ended, constituting thus a normative demand according to which the Montenegrin legal order would have to be factually reinstated as well.

However this normative demand was challenged by another normative demand arising from the principle of self-determination of 
Montenegrin people, and the two found themselves in collision. The letter normative demand was both allowed to arise and later be adjudicated as superior to the former by the international legal order, the same legal order which provides the basis for the first normative demand in first place. Therefore, legally speaking, everything took place within and according to the rules of a single legal order - both the birth, the survival and the end of the Montenegrin legal order.

It is therefore, impossible to claim that the unification hadn't been legal because the very precondition to acknowledging any validity of the Montenegrin legal order at the time of the unification is recognizing the existence of international legal order and its rules. However, once we base the validity of a certain order on the international legal order, we have subjected the overall validity and fate of that order to the supreme international order. Therefore, we cannot argue that once the adjudicators of the international legal order ruled that a certain norm gained superiority over the previous one, even if according to that letter norm our whole order is canceled - that such a decision had been illegal and that such a norm hadn't become legal. For we owe all our legality and existence to the superior order, which is the well of all validity. This is, in short, the mistake in which all those who claim that the unification hadn't been legal fall in. Because, the only way to prove that the Montenegrin legal order existed and was valid despite the three years long occupation and ineffectiveness is to base it on the basis of the international law, to say that it was in power because international law defined so. However, if we then go on to prove how the decision of the Assembly of 1918 and its validation had been invalid, we cannot ignore the fact that the ultimate basis of our legal order and its overall existence lays too in the fact that the international legal order recognized it as valid and existing. This means that, should the international legal order grant validity to the decision of Podgorica Assembly (which brings an end to the country), we can either chose to accept this decision's legality, which means accepting the legality the country's end - or we can chose to deny this decision's authority and legality, which would also ultimately mean denying the validity of the source our country's legal existence is derived from, leaving it ultimately too outside of (legal) existence. 


\section{REFERENCES}

1. Craven, Matthew. 1998. The Problem of State Succession and the Identity of States under International Law, European Journal of International Law 9: $142-162$.

2. Dinstein, Yoram. 2009. The International Law of Belligerent Occupation. Cambridge: Cambridge University Press.

3. Fisch, Jörg. 2015. The Right of Self-Determination of Peoples: The Domestication of an Illusion. Cambridge: Cambridge University Press.

4. Jovanović, Miodrag. 2019. The Nature of International Law, Cambridge: Cambridge University Press.

5. Kelsen, Hans. 2006. The General Theory of Law and State. New Bruswick - New Jersey: Transaction Publishers.

6. Kelzen, Hans. 2003. Problem suverenosti i teorija međunarodnog prava. Beograd: Službeni list SRJ.

7. Neiberg, Michael S. 2017. The Treaty of Versailles: A Concise History, Oxford: Oxford University Press.

8. Shaw, Malcom N. 2003. International Law, Cambridge: Cambridge Unversity Press.

9. Vukčević, Marina, Šerbo Rastoder. 2000. Uloga Francuske u nasilnoj aneksiji Crne Gore. Bar: CONTECO.

10. Bojović, Jovan. 1989. Podgorička skupština 1918: dokumenta. Gornji Milanovac: Dečje Novine

11. Vujović, Dimitrije. 1962. Ujedinjenje Crne Gore i Srbije, Titograd: Istorijski institut Narodne Republike Crne Gore.

12. Rakočević, Novica. 2018. Crna Gora u Prvom svijetskom ratu. Novi Sad Beograd: Prometej - Radio-televizija Srbije.

13. Mitrović, Andrej. 2019. Jugoslavija na konferenciji mira 1919-1920. Novi Sad - Beograd: Prometej - Radio-televizija Srbije.

14. Šuković, Mijat. 2003. Studije i eseji iz istorije Crne Gore. Podgorica: Pravni fakultet. 